\title{
Association between Floral Bud Size and Developmental Stage in Soybean Microspores
}

\author{
Mozart da Silva Lauxen ${ }^{1}$, Eliane Kaltchuk-Santos ${ }^{1}$, Ching-yeh $\mathbf{H u}^{2}$, Sidia Maria Callegari- \\ Jacques $^{1,3}$ and Maria Helena Bodanese-Zanettini ${ }^{1 *}$ \\ ${ }^{1}$ Departamento de Genética; Universidade Federal do Rio Grande do Sul; Porto Alegre - RS - Brazil. ${ }^{2}$ Biology \\ Department; William Paterson College of New Jersey; Wayne; NJ07470; USA. ${ }^{3}$ Departamento de Estatística; \\ Universidade Federal do Rio Grande do Sul; Porto Alegre - RS - Brazil
}

\begin{abstract}
This study was carried out to establish the association between floral bud size and the corresponding microspore developmental stages for Brazilian soybean cultivars. Microspore developmental stage distributions were examined in young buds from cv Década, IAS5 and RS7. The data indicated that for a given bud-size group, the microspores of different cultivars were at different developmental stages, with cv RS7 and Década distributed at the youngest and $c v$ IAS5 at the most advanced stages. Microspore stages distribution were also compared among the ten anthers of the same bud of the above cultivars. The ten anthers from a given bud were clearly distributed at different developmental stages. Caution should be exercised when adopting the standard anther culture practice of using the microspore stage of one anther to represent the entire bud.
\end{abstract}

Key words: Glycine max, soybean, microsporogenesis, anther culture

\section{INTRODUCTION}

Numerous factors have been described to influence the induction of pollen embryogenesis. One of the most crucial parameters for success is obtaining the proper stage of microspore development at culture initiation (Chuong et al., 1988). Although the growth conditions influence the morphology of the donor plants, it is possible to correlate the stages of microspore development with other morphometric attributes of the plant.

In Nicotiana, a good relationship exists between the stage of anther development and flower bud length (Kasperbauer and Wilson, 1979). In tomato (Lycopersicon esculentum), both anther and flower bud length were significantly correlated with anther developmental stage (Summers et al., 1992). In Lesquerella fendleri, a member of the Brassicaceae, Tomasi et al. (1999) found that several morphometric parameters were correlated with microspore stage, with the most significant correlation being with the mean length of the two largest petals.

The correspondence of microsporogenesis stages to the external floral bud features in soybean (Glycine max) was first established by Ivers et al. (1974) for cv Hank. These authors selected and cultured the anthers of stage 3 buds, having 2.5 $\mathrm{mm}$ bud length with predominantly individualized, uninucleate and devoid of starch microspores.

In soybean floral bud development, the bract/bud ratio is progressively reduced as the bud grows.

\footnotetext{
* Author for correspondence
} 
The correlation between the floral bud morphological size index and the microspore developmental stages for Chinese soybean cultivars was established by Yin et al. (1982) based on bract/bud ratio. These authors reported that when the bract length was the same as the bud length, the microspores were at the tetrad stage. When the bract was equal to $3 / 4-2 / 3$ of the bud length (bud length $=2.5$ to $3.5 \mathrm{~mm}$ ) the microspores were at the uninucleate stage. This was the stage of buds they selected to culture. In this size range, the microspores ranged from an early uninucleate stage with a centrally located nucleus, to the mid-uninucleate stage with the nucleus moved off center, and to a lateuninucleate stage with the nucleus against the pollen wall. When the bract length reached $1 / 2$ the bud length, the microspores were at the binucleate stage.

Larger buds, with the bract/bud ratio between $2 / 3$ to $1 / 3$, were cultured by X.J. Zhuang and C.Y. Hu (see $\mathrm{Hu}$ et al., 1996) using U.S. cultivars Williams 82 and Asgrow A1929. They reported that buds with a bract/bud ratio of $2 / 3$ and a bud length of $3.9 \pm$ $0.63 \mathrm{~mm}$ had $57 \%$ and $42 \%$ of the microspores at the uninucleate and binucleate stages, respectively, and $12 \%$ were empty ones. Buds with a ratio of $1 / 3$ and a length of $5.0 \pm 0.67 \mathrm{~mm}$ had less than $1 \%$ and $67 \%$ of the microspores at the uninucleate and binucleate stages, respectively, and the frequency of empty microspores increased to $33 \%$.
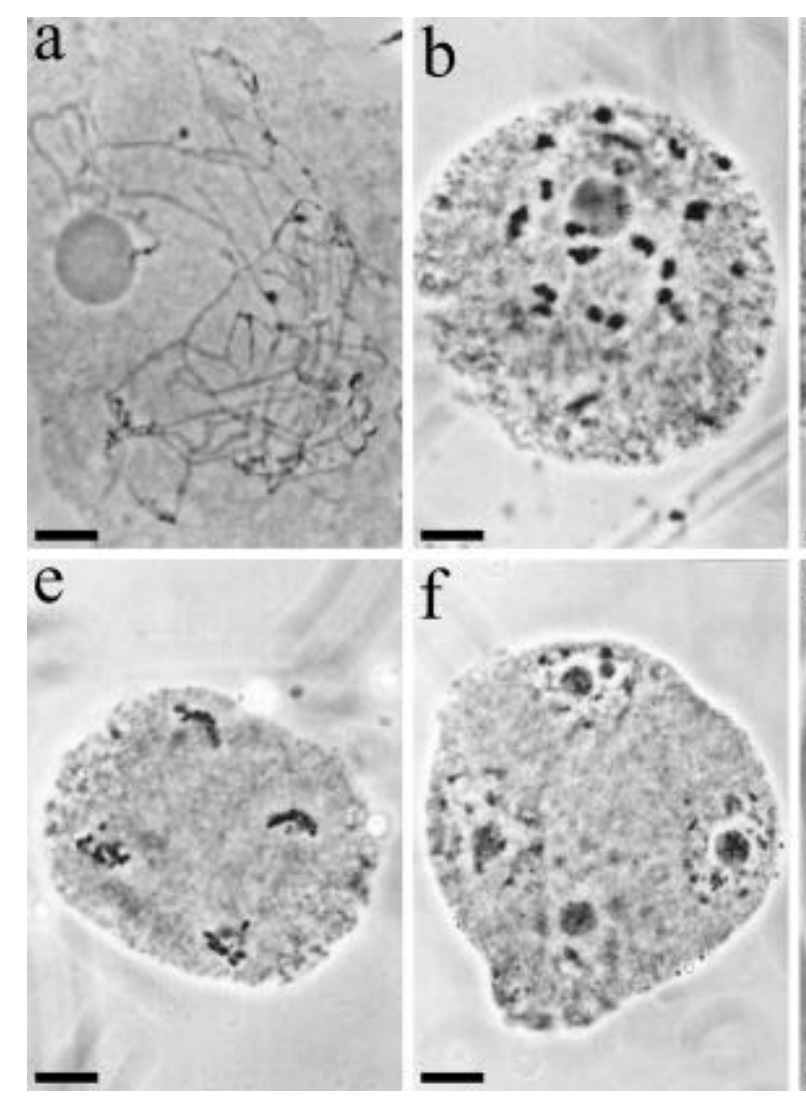
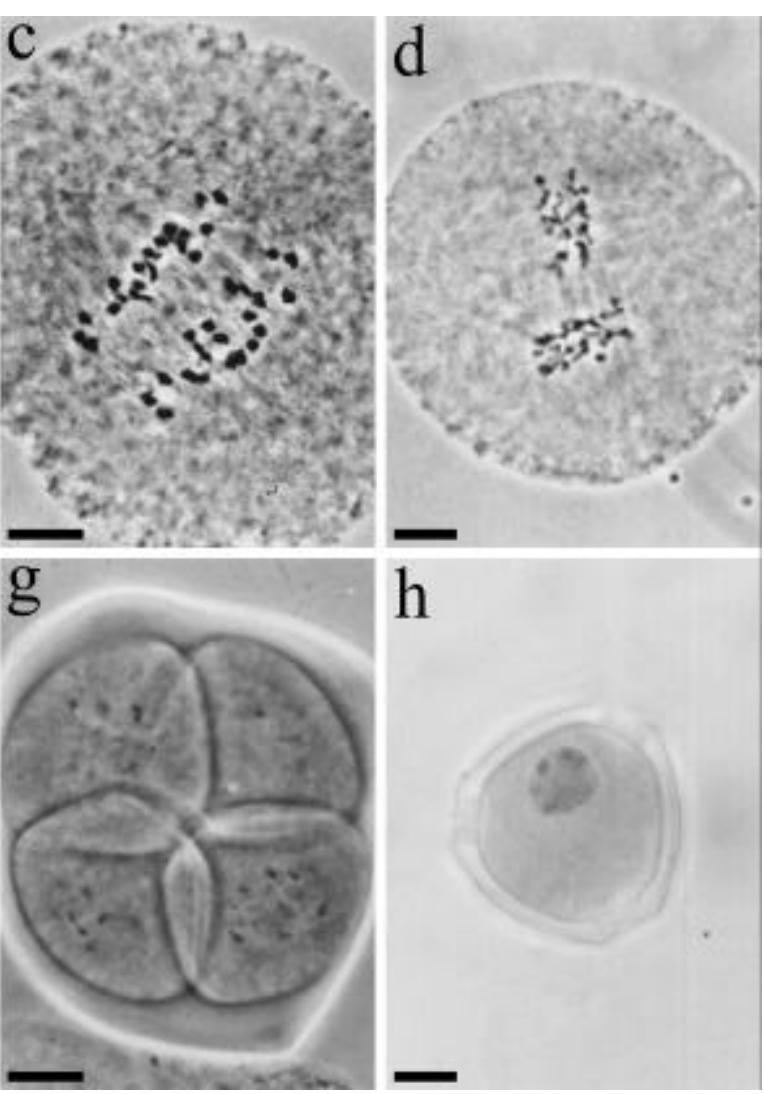

Figure 1 - Representative stages of soybean microspore development: a) zygoneme, b) diakinesis, c) anaphase I, d) metaphase II, e) anaphase II, f) coenocytic tetrad, g) tetrad, and h) late uninucleate microspore. $\mathrm{Bar}=10 \mu \mathrm{m}$.

To establish similar information for the anther culture of Brazilian soybean cultivars, we made detailed examinations of the microsporogenesis stage distributions of $1.5-3.5 \mathrm{~mm}$ long floral buds of three cultivars. It is generally assumed that all the anthers of the same bud contain microspores at the same developmental stage. As a common practice, one anther from each bud is placed in fixative for microspore stage determination while the remaining anthers of the same bud are 
cultured. Based on the anther sizes and coloration of anther walls, the ten anthers in a given soybean floral bud, especially those with microspores prior to the binucleate stage, seemed to present somewhat different developmental stages. To verify this point, we have also examined the microspore stages of the individual anthers in the same bud.

This investigation is part of an effort we are carrying to obtain basic information on soybean anther culture. It is our hope that our results will shed some light on this slow-developing but important field of research.

\section{MATERIALS AND METHODS}

Soybean (Glycine $\max (\mathrm{L}$.) Merr.; $2 \mathrm{n}=40$ ) of cultivars Década, IAS5 and RS7 were used in this study. Young inflorescences of field-grown plants were harvested in February (summer) of 1995 and 1997 at their early flower production period. To study the distribution of microspore developmental stages of buds of different sizes, ten buds from each sized group of $1.5-1.9,2.0-2.4,2.5-2.9$ and $3.0-3.5 \mathrm{~mm}$ were sampled from each cultivar/year. To study the distribution of microspore developmental stages of the ten anthers from the same bud, individual anthers of a given bud were examined separately. Eight buds were sampled from each cultivar.

Floral buds were measured prior the fixation in 3:1 (100\% ethanol : glacial acetic acid) at room temperature for $24 \mathrm{~h}$ and stored in $70 \%$ ethanol at $20^{\circ} \mathrm{C}$ before analysis. At the time of analysis, anthers were dissected out from the buds and squashed in propionic carmine on glass slides and sealed under cover slips with bee's wax. Microspores were staged and classified under a Zeiss Axioplan Universal microscope. For recording purposes, we divided all the observed developmental phases into 18 stages during the cytological examinations: sporogeneous cells, interphase, leptoneme, zygoneme, pachyneme, diploneme, diakinesis, metaphase I, anaphase I, telophase I, prophase II, metaphase II, anaphase II, telophase II, coenocytic tetrad, tetrad, young uninucleate microspore and late uninucleate microspore. Some of the most representative stages are presented (Fig. 1).
Considering the nature of the data, nonparametrical methods were employed in the statistical analysis. Inside each cultivar bud-size group, the analyzed buds were ranked in ascending order in accordance with their progress in microsporogenesis. Three analyses were effectuated: (a) Comparison among the four size groups inside each cultivar/year: $\mathrm{N}=40$ buds, Kruskal-Wallis followed by a nonparametric multiple comparison test analog to the StudentNewman-Keuls multiple range test (Zar, 1999); (b) Comparison between years 1995 and 1997 for each cultivar: $\mathrm{N}=80$, Wilcoxon-Mann-Whitney (WMW) test; and (c) Comparison among cultivars for each year: $\mathrm{N}=120$, Kruskal-Wallis as in (a).

As different development stages in a bud were a common observed pattern, the informationtheoretic diversity measure of Brillouin (Zar, 1999) was used to measure the relative diversity among anthers within a given flower.

\section{RESULTS}

The distribution of microspore stages of four budsize groups for each cultivar/year is diagrammatically presented (Fig. 2). To simplify data presentation, we have reduced the 18 recorded stages, from sporogeneous cells to latephase microspore (late uninuclear), into 13 stages based on the duration of the developmental periods. Since the prophase of the first meiosis lasted a long time, we kept on dividing it into subphases; while the second meiotic division was very brief, we lumped all its phases together into one stage.

\section{Intra-cultivar Analysis}

In all three cultivars the stage of development varied significantly among bud-size classes (Década 1995: $\mathrm{H}_{\mathrm{c}}=9.80, \mathrm{p}<0.05$; Década 1997: $\mathrm{H}_{\mathrm{c}}=31.22, \mathrm{p}<0.05$; IAS5 1995: $\mathrm{H}_{\mathrm{c}}=32.52, \mathrm{p}<$ 0.05; IAS5 1997: $\mathrm{H}_{\mathrm{c}}=31.34, \mathrm{p}<0.05$; RS7 1995: $\mathrm{H}_{\mathrm{c}}=28.77, \mathrm{p}<0.05$; RS7 1997: $\mathrm{H}_{\mathrm{c}}=33.31, \mathrm{p}<$ 0.05). However, in buds collected in 1995, this overall difference was not confirmed in size classes 1 and 2 for RS7 ( $q=2.27, p>0.10)$ and 1 , 2 and 3 for $\mathrm{cv}$ Década (q values ranging from 0.88 to $1.15, \mathrm{p}>0.20$ ). 

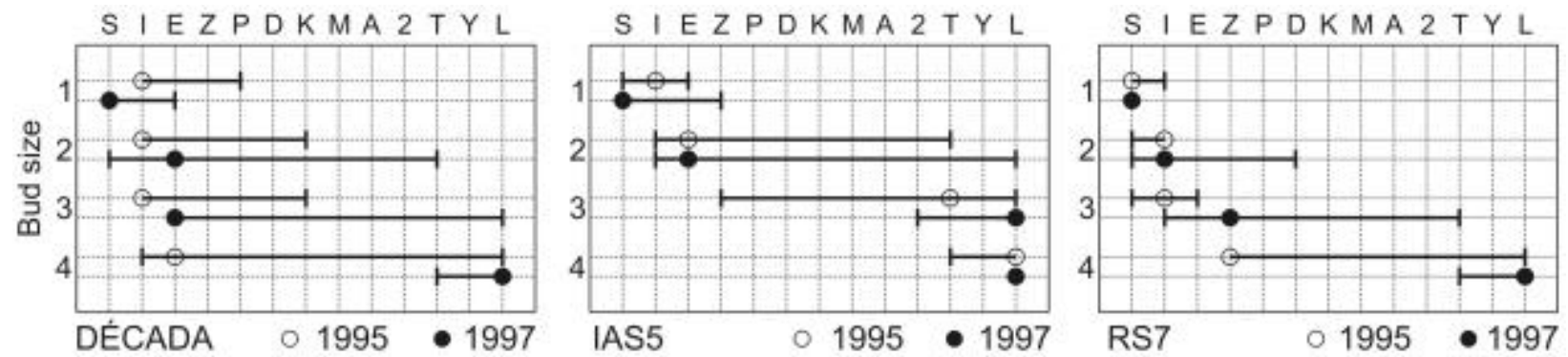

Figure 2 - Microspore developmental stage distribution (circles: mode; solid lines: other stages observed) in the immature floral buds of Brazilian soybean cv Década, IAS5 and RS7. Bud size groups: 1) 1.5 $1.9 \mathrm{~mm}$, 2) $2.0-2.4 \mathrm{~mm}, 3) 2.5-2.9 \mathrm{~mm}$, and 4) $3.0-3.5 \mathrm{~mm}$. Ten buds for each size group / cultivar were sampled / year. Symbols: $\mathrm{S}=$ sporogeneous cells, $\mathrm{I}=$ interphase, $\mathrm{E}=$ leptoneme, $\mathrm{Z}=$ zygoneme, $\mathrm{P}=$ pachyneme, $\mathrm{D}=$ diploneme, $\mathrm{K}=$ diakinesis, $\mathrm{M}=$ metaphase, $\mathrm{A}=$ anaphase, $2=2^{\text {nd }}$ meiotic division, $\mathrm{T}=$ tetrad, $\mathrm{Y}=$ young uninucleate microspore, $\mathrm{L}=$ late uninucleate microspore.
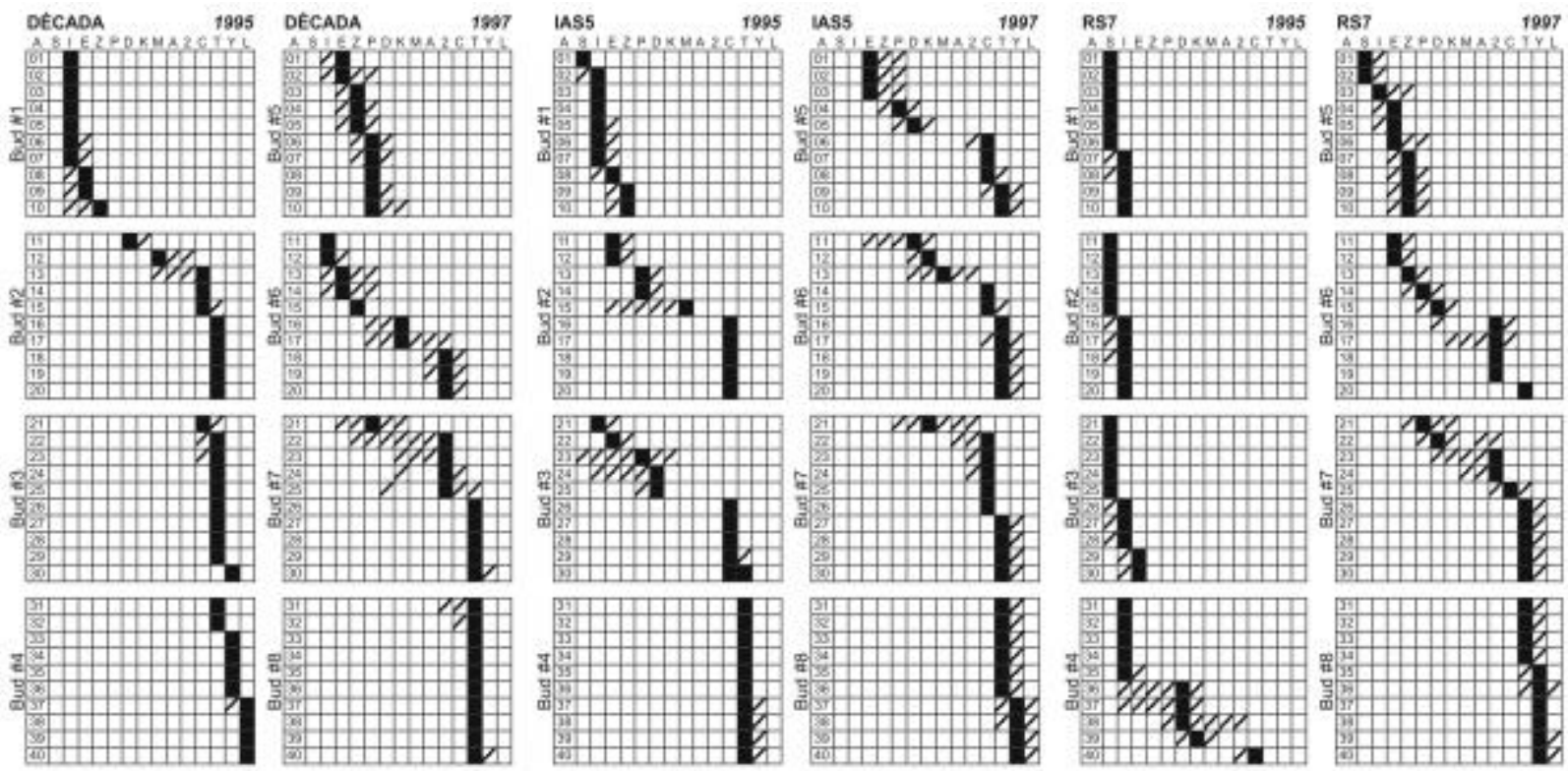

Figure 3 - Microspore developmental stage distribution in the ten anthers of each floral bud of Brazilian soybean cv Década, IAS5 and RS7. The examined bud sizes ranged from 2.5 to $3.0 \mathrm{~mm}$. Eight buds from each cultivar were examined. Symbols: $\mathrm{A}=$ anther number, $\mathrm{S}=$ sporogeneous cells, $\mathrm{I}=$ interphase, $\mathrm{E}=$ leptoneme, $\mathrm{Z}=$ zygoneme, $\mathrm{P}=$ pachyneme, $\mathrm{D}=$ diploneme, $\mathrm{K}=$ diakinesis, $\mathrm{M}=$ metaphase, $\mathrm{A}=$ anaphase, $2=2^{\text {nd }}$ meiotic division, $\mathrm{C}=$ coenocytic tetrad, $\mathrm{T}=$ tetrad, $\mathrm{Y}=$ young uninucleate microspore, $\mathrm{L}=$ late uninucleate microspore. Black blocks: modal stages, striped blocks: also observed stages.

No difference was observed between years in the three cultivars (Década: $\mathrm{z}(\mathrm{WMW})=0.70, \mathrm{p}=$ 0.481; IAS5: $\mathrm{z}(\mathrm{WMW})=0.87, \mathrm{p}=0.383$; RS7: $\mathrm{z}(\mathrm{WMW})=1.76, \mathrm{p}=0.078)$.

\section{Inter-cultivar Analysis}

A different average pattern of development was observed among cultivars in year $1995\left(\mathrm{H}_{\mathrm{c}}=\right.$ 22.41, $\mathrm{p}<0.001)$, RS7 showing a late microsporogenesis, IAS5 an earlier one and, Década, intermediate phases (multiple comparisons: $\mathrm{q}$ ranging from 4.37 to $5.56, \mathrm{p}<0.05$ ).

A significant difference was again observed in 1997 $\left(\mathrm{H}_{\mathrm{c}}=8.41, \mathrm{p}=0.015\right)$, IAS5 showing the earliest microsporogenesis while Década and RS7 did not differ between themselves $(q=2.164, p>0.10)$.

The distribution of microspore stages of ten individual anthers of the same bud for each 
cultivar is diagrammatically presented (Fig. 3). We have reduced the 18 recorded stages into 14 stages. Almost $92 \%$ of the analysed buds showed at least 2 anthers in different stages of development $(\bar{X} \pm$ $\mathrm{SD}=5.5 \pm 1.7$ synchronous anthers), with similar relative diversity indexes in all $3 \mathrm{cv}$ : Década: $\mathrm{J}_{\text {MEAN }}=0.44$ (range: $0-0.74$ ); IAS5: $\mathrm{J}_{\text {MEAN }}=0.49$ (range: $0-0.72$ ); and RS7: $\mathrm{J}_{\text {MEAN }}=0.52$ (range: $0.35-0.74)$.

\section{DISCUSSION}

For anther culture of Chinese cultivars, the ideal microspore developmental stage was determined to be the one from early to mid-uninucleate stage (Yin et al., 1982; Ye et al., 1994). When anthers with microspores at the late-uninucleate and binucleate stages were cultured, a gradual blackening of the anther wall was observed with the disintegration of the microspores into hollow ghosts (Yin et al., 1982). With U.S. cultivars, Zhuang and $\mathrm{Hu}$ (unpublished data) obtained large amounts of calli with anthers containing lateuninucleate and binucleate microspores. Anthers containing uninucleate microspores remained quiescent in the culture.

In our study, differences in developmental stages were observed among cultivars, confirming previous observations (Kaltchuk-Santos et al., 1997). Microspores of RS7 and Década were at an earlier developmental stage than those of IAS5. Assuming that the microspores from the early to late uninucleate stages are the most responsive for the anther culture of Brazilian soybean, the bud size selection for cv IAS5 should be $2.5-3.5 \mathrm{~mm}$. Larger buds, probably $3.0-4.0 \mathrm{~mm}$, should be selected for cv Década and RS7.

Although our sample sizes were small and some of the less frequent microspore stages might have escaped recording, we have determined that, comparing cultivars, buds of the same size necessarily do not have microspores at the same stage. In addition, the three cultivars studied showed that microspores from different anthers of the same flower are not at the same developmental stage. This result can be accounted for the slightly temporal difference in the appearing of stamens in the flower development, since the lower whorl of five stamens arises only just before the last stamen of the upper whorl has appeared (Carlson and Lersten, 1987). Our results confirm (data not shown) that microsporogenesis in stamens of lower whorl is delayed when compared with stamens of upper whorl.

A standard practice in anther culture is to save one anther from each bud during culture dissection for the microspore stage determination of that particular bud. Since the individual anthers of the same bud in soybean are not necessarily at a unified stage, caution must be taken when adopting such practice.

Our results, as observed by Sunderland (1974), indicate caution in using floral bud morphological size index as a criterion of determining the microspore developmental stages for soybean. There were not only cultivar differences, but also bud-to-bud variations from either the same or different plants (Figs. 2 and 3). Plant to plant microspore stage variations from the same bud size have also been observed in Datura (Sunderland et al., 1974). Thus, in soybean, the association between bud size and microspore stage should be re-checked under each different situation, such as cultivar, donor plant age, donor plant growth environments, etc.

It is important to have the correct determination of microspore stage in anther culture, since microspore stage not only affects the percentage of pollen grains responding to the culture conditions, but also because it affects the ploidy of the resulting embryos. It is well documented in several species that the younger microspores produced higher percentages of haploid embryos while microspores at more advanced stages frequently gave embryos of higher ploidies (review in Sunderland, 1974). The microspore stage variations revealed by our study might very well be one of the factors which has contributed to the slow progress of soybean anther culture.

\section{ACKNOWLEDGEMENTS}

This study was supported by $\mathrm{CNPq}$ (Conselho Nacional de Desenvolvimento Científico e Tecnológico), FAPERGS (Fundação de Apoio à Pesquisa do Estado do Rio Grande do Sul) and FINEP (Financiadora de Estudos e Projetos). 


\section{RESUMO}

Este estudo visa estabelecer a associação entre o tamanho do botão floral e o estágio de desenvolvimento dos micrósporos em cultivares brasileiras de soja. A distribuição dos estágios de desenvolvimento dos micrósporos foi analisada, nos anos de 1995 e 1997, em botões florais jovens das cultivares Década, IAS5 e RS7. Os dados indicam que, para um dado intervalo de tamanho do botão floral, os micrósporos das diferentes cultivares estavam em distintos estágios de desenvolvimento, com as cultivares RS7 e Década exibindo estágios anteriores àqueles observados na cultivar IAS5. A distribuição dos estágios dos micrósporos entre as dez anteras de um mesmo botão floral foi também analisada nestas cultivares. As dez anteras de um mesmo botão estão claramente distribuídas em diferentes estágios de desenvolvimento. Cautela deve ser tomada ao adotar-se o procedimento padrão em cultura de anteras de utilizar o estágio de desenvolvimento dos micrósporos em uma única antera para representar a totalidade do botão floral.

\section{REFERENCES}

Carlson, J. B. and Lersten, N. R. (1987), Reproductive Morphology. In: Soybeans: Improvement, Production, and Uses. Agronomy, 16, 95-134.

Chuong, P. V.; Deslauriers, C.; Kott, L. S. and Beversdorf, W. D. (1988), Effects of donor genotype and bud sampling on microspore culture of Brassica napus. Can. J. Bot., 66, 1653-1657.

Hu, C. Y.; Yin, G. C. and Zanettini, M. H. (1996), Haploid of soybean. In: Jain, S. M.; Sopory, S. K. and Veilleux, R. E. (Eds.). In vitro haploid production in higher plants. Dordrecht : Kluwer Acad. Publ. pp. 377-395.

Ivers, D. R.; Palmer, R. G. and Fehr, W. R. (1974), Anther culture in soybean. Crop. Sci., 14, 891-893.

Kaltchuk-Santos, E.; Mariath, J. E.; Mundstock, E.; Hu, C.Y. and Bodanese-Zanettini, M. H. (1997), Cytological analysis of early microspore divisions and embryo formation in cultured soybean anthers. Plant Cell, Tissue and Org. Cult., 49, 107-115.

Kasperbauer, M. J. and Wilson, H. M. (1979), Haploid plant production and use. In: Durbin, R. D. (Ed.). Nicotiana procedures for experimental use. Washington, DC : USDA Technol. Bul. 1586. pp. 33-39.
Summers, W. L.; Jaramillo, J. and Bailey, T. (1992), Microspore developmental stage and anther length influence the induction of tomato anther callus. Hort. Sci., 27, 838-840.

Sunderland, N. (1974), Anther culture as a means of haploid production. In: Kasha, K. J. H. (Ed.). Haploids in higher plants. Advances and potential. Univ. of Guelph, Guelph. pp. 91-122.

Sunderland, N.; Collins, G. B. and Dunwell, J. M. (1974), Nuclear fusion in pollen embryogenesis of Datura innoxia Mill. Planta (Berl.), 117, 227-241.

Tomasi, P.; Dierig, D. A.; Backhaus, R. A. and Pigg, K. B. (1999), Floral bud and mean petal length as morphological predictors of microspore cytological stage in Lesquerella. Hort. Sci., 34, 1269-1270.

Ye, X. G.; Fu, Y. Q. and Wang, L. Z. (1994), Study on several problems of soybean anther culture. Soybean Sci., 13, 193-199.

Yin, G. C.; Zhu, Z. Y.; Xu, Z.; Chen, L.; Li, X. Z. and Bi, F. Y. (1982), Studies on induction of pollen plant and their androgenesis in Glycine $\max (\mathrm{L}$.$) Merr.$ Soybean Sci., 1, 69-76.

Zar, J. H. (1999), Biostatistical Analysis, 4. ed. New Jersey : Prentice-Hall.
Received: October 16, 2001; Revised: June 27, 2002; Accepted: October 22, 2002. 